\title{
Optimization of a Tiger Nut-Based Yoghurt Formulation by Response Surface Methodology
}

\author{
Bou Ndiaye ${ }^{1,2}$, Mama Sakho1,2, Nicolas Cyrille Ayessou, ${ }^{1,2}$, Omar Ibn Khatab Cisse ${ }^{1,2}$, \\ Mady Cisse ${ }^{1,2}$, Codou Mar Diop1,2 \\ ${ }^{1}$ Laboratory of Electrochemistry and Membrane Processes, Polytechnic High School of Dakar, Cheikh Anta Diop \\ University, Dakar, Sénégal \\ ${ }^{2}$ Center for Studies on Food Safety and Functional Molecules (CESAM-RESCIF), Dakar, Sénégal \\ Email: cheikbou20@yahoo.fr
}

How to cite this paper: Ndiaye, B., Sakho, M., Ayessou, N.C., Cisse, O.I.K., Cisse, M. and Diop, C.M. (2019) Optimization of a Tiger Nut-Based Yoghurt Formulation by Response Surface Methodology. Food and Nutrition Sciences, 10, 1400-1418. https://doi.org/10.4236/fns.2019.1012100

Received: May 13, 2019

Accepted: December 14, 2019

Published: December 17, 2019

Copyright $\odot 2019$ by author(s) and Scientific Research Publishing Inc. This work is licensed under the Creative Commons Attribution International License (CC BY 4.0).

http://creativecommons.org/licenses/by/4.0/

\begin{abstract}
Tiger nut is a comestible tuber which offers many under products such as yoghurt. The parameters influencing the quality of yoghurt being numerous, response surface methodology was used to optimize the formulation in order to reach a low intake of milk powder. The volume of tiger nut milk, mass milk powder and sugar mass are the factors monitored while the titratable acidity (AT), pH, dry soluble extract (ESS), ash, viscosity and color are the expected responses in these tests. The data are processed with a degree of confidence $\mathrm{p}<0.05$ associated with statistical analysis by the software Statgraphic Centurion XVI version 16.2.04. The different tests show that the factors have overall significant effects $(\mathrm{p}<0.05)$ on the acidity, the ashes and the Whiteness index. The linear and quadratic factors of tiger nuts milk as well as those linears of the milk powder have significant effects $(\mathrm{p}<0.05)$ on the $\mathrm{pH}$ and the ashes. The linear factors of milk powder have significant effects on DSE, AT and $\mathrm{pH}$. The optimal formulation yielded a volume of tiger nut milk equal to $3.7 \mathrm{~L} / \mathrm{kg}$, a mass of powder milk of $63.4 \mathrm{~g}$ and $75 \mathrm{~g}$ of sugar for one kilogram of yogurt. With a desirability of $75 \%$, this model is apt to explain the results and the experimental values fit with the predicted ones and are within the norms. The proximate analysis of optimal yoghurt formulation shows that fat and proteins contents are respectively $5.67 \%$ and $2.2 \%$. Calcium, magnesium and potassium contents are respectively 160, 40 and 180 $\mathrm{mg}$ in $100 \mathrm{~g}$ of yoghurt.
\end{abstract}

\section{Keywords}

Optimization, Tiger Nut, Yoghurt 


\section{Introduction}

The inadequacy of the distribution of plant resources around the world and the lack of processing of available resources in some parts of the world mean that today a large part of the world's population still suffers from the consequences of malnutrition. The latter remains a real scourge and one of the major public health problems in the world despite the considerable progress made. It is thought to be responsible for almost 55\% of all deaths among children aged from 0 to 5 years, and this proportion is higher in poor countries; particularly in Africa. Nowadays, one of the axes of research in the field of food sciences is the development of functional foods that provide health benefits [1] [2] [3]. Tiger nut is one of the underused tubers in West Africa, which presents an interesting amino acids profile [4] [5], displaying high levels of essential fatty acids [5], soluble fibers, vitamins, minerals [6] [7] and phytochemicals such as isoflavones, flavonoids, terpenoids, alkaloids and saponins [8] [9]. The latter are known for their biological properties. Recent studies have proved the biological effects exhibited by the tiger nut tubers, such as anti-diabetic, cholesterol-lowering, hepatoprotective, aphrodisiac [10] [11] [12] [13], antibacterial [9] and galactogenic [14]. The diversity of tiger nuts based-products allows populations to benefit from its properties. In fact, the development of new fermented products based on tiger nut would procure specific healthy advantages for populations, compared to the conventional yogurts sold in the market. For the sake of minimising the powdered milk input during the production of this tiger nut-based yogurt, this study has been performed by varying the required volume of the tiger nut milk from a constant mass (tiger nut milk concentration) and adding sugar using design of experiments to optimize the process of tiger nut-based yogurt.

\section{Material and Methods}

\subsection{Plant Material}

The tiger nut tubers (Cyperus esculentus) represent the basic raw material for this present study (Figure 1). Tiger nut samples were obtained from local market. The samples were separated from stalks and stem and washed thoroughly under running water to remove dirt and weighed.

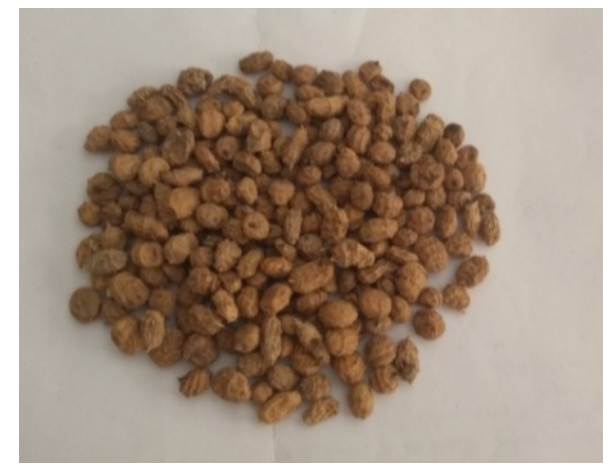

Figure 1. Dry tiger nut. 


\subsection{Extraction of the Tiger Nut Milk}

The tiger nut tubers and the powdered milk used in this work were bought from the local market. The tubers have been cleaned many times with tap water before being soaked in water for twelve hours. Tubers after soaking are represented in Figure 2. Various concentrations have been set following the formulations. The milk is obtained by using a mixer of the brand Moulinex (France) at the maximum vitesse for $40 \mathrm{~s}$ three times, mixing the tubers with water. The blended mixture is then filtering throught a muslin cloth two times.

\subsection{Preparation of the Yoghurt}

The extracted tiger nut milk has been mixed with a mass of milk and sugar according to the different formulations described by the design of experiments in order to obtain a final mass of $1 \mathrm{~kg}$ of yogurt. The pasteurization is carried out at $75^{\circ} \mathrm{C}$ during 5 minutes and then the mix is transferred into jars for fermentation at $45^{\circ} \mathrm{C}$ during 4 hours in an incubator and they are removed to be cooled.

\subsection{Experimental Design and Statistical Analysis}

Box-Behnken design are used in this study for the conception of the design of experiments. The response surface methodology (RSM) has been applied to optimize the factors and study the influences of the volume of tiger nut milk $\left(X_{1}\right)$ (concentration), of the mass of powdered milk $\left(X_{2}\right)$ and the mass of sugar $\left(X_{3}\right)$ on the responses. The tiger nut milk volume extracted from $1 \mathrm{~kg}$ of tiger nut tuber ranges from 2 liter to 5 liter, the masse of milk powder varies between $20 \mathrm{~g}$ and $120 \mathrm{~g}$ and sugar mass ranges from $50 \mathrm{~g}$ to $75 \mathrm{~g}$. These values are taken in order to produce a firm yoghurt. The $\mathrm{pH}$, titratable acidity, total soluble dry extract (SDE), viscosity, ashes content and color of the yogurt from the different formulations were evaluated as responses for the factors studied. The real levels of the variables are indicated in Table 1. Statgraphic centurion XVI Version 16.2.04 (32-bits) software was used for analysis. A second order polynomial regression model was applied to express the dependent variables as a function of the independent variables where $Y$ is the measured response associated to each

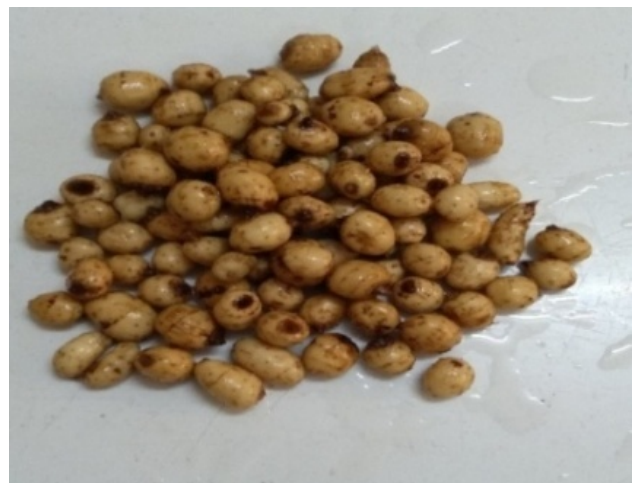

Figure 2. Tiger nut tuber after 12 hour soaking. 
Table 1. Level and code of independent variables, volume (tiger nut milk), mass of sugarand, mass of milk level used for Box-Behnken experimental design.

\begin{tabular}{cccccc}
\hline Independent variables & Symbol & Unit & Minimum & Level & Maximum \\
\hline & & & -1 & 0 & 1 \\
Volume (tiger nut milk) & $X_{1}$ & $1 / \mathrm{kg}$ & 2 & 3.5 & 5 \\
Mass of sugar & $X_{2}$ & $\mathrm{G}$ & 50 & 62.5 & 75 \\
Mass of milk & $X_{3}$ & $\mathrm{G}$ & 20 & 70 & 120 \\
\hline
\end{tabular}

Note: $X_{1}(\mathrm{~A}), X_{2}(\mathrm{~B}), X_{3}(\mathrm{C}), X_{1} X_{2}(\mathrm{AB}), X_{1} X_{3}(\mathrm{AC}), X_{2} X_{3}(\mathrm{CB}), X_{11}(\mathrm{AA}), X_{22}(\mathrm{BB})$ and $X_{33}(\mathrm{CC}), X_{1}, X_{2}$ and $X_{3}$ mean respectively the letter $\mathrm{A}, \mathrm{B}$ and $\mathrm{C}$ in the response surface and PARÉTO graphic.

combination of factor levels; $\beta_{0}$ is a constant; $\beta_{i}$ is the regression coefficient calculated from the observed experimental values of $Y_{\dot{i}}$. The terms $X_{p} X_{i} X_{j}$ and $X_{i}^{2}$ represent the interaction and the quadratic terms, respectively.

\section{Physicochemical Analysis}

\section{1) $\mathrm{pH}$ and titratable acidity}

The samples were analysed to get $\mathrm{pH}$ and titratable acidity as described by Olubamiwa et al. (2006). A pH-meter of the brand Hanna HI-98128 was utilized to evaluate the $\mathrm{pH}$ of the different formulations of yogurt. The acidity has been measured by titration of $10 \mathrm{ml}$ of yogurt with $\mathrm{NaOH} 0.1 \mathrm{~N}$; and was expressed in equivalent gram of lactic acid/100g.

\section{2) Viscosity and color}

Yoghurt samples were gently stirred with a plastic spoon prior to viscosity measurements. The viscosity was measured at $7^{\circ} \mathrm{C}$ using a Brookfield digital viscometer and is expressed in $\mathrm{Cp}$. The color was measured with a colorimeter (CM-3600d, MINOLTA Co.; Japan) of the model D25A-9. The coordinates CIE Lab was obtained with the illuminating observer D65/10 . The color parameters such as $L, a^{*}, b^{*}, c^{*}$ and $h^{*}$ were given by the colorimeter directely and are used to calculate the whiteness index (WI) and total color (TC) according to [15] and [16],

$$
\begin{gathered}
\mathrm{WI}=100-\sqrt{(100-L)^{2}+a^{* 2}+b^{* 2}} \\
\mathrm{TC}=\sqrt{L^{2}+a^{* 2}+b^{* 2}}
\end{gathered}
$$

\section{3) Physicochemical properties analysis}

The ash content was determined according the [17] method. Two grams of the sample flours were weighed into the crucible and the weight taken. The crucible containing the samples were placed into the muffle furnace and ignited at $550^{\circ} \mathrm{C}$. This temperature was maintained for three hours. The dry soluble extract was determined by using refractometer (ATAGO B024889 JAPON). Fat was determined in the soxhlet apparatus (AOAC, 1990) using hexane as the solvent of extraction. The Kjeldahl procedure based on the AOAC (1990) method was used for the protein content determination.

\section{4) Resultats and discussion}

The analysis results are set out in Table 2 and show the different variations 
Table 2. The experimental design and obtained values of the responses.

\begin{tabular}{|c|c|c|c|c|c|c|c|c|c|c|c|}
\hline \multirow[b]{2}{*}{ Sample } & \multirow[b]{2}{*}{$\begin{array}{l}\text { Volume } \\
\text { (l) }\end{array}$} & \multirow[b]{2}{*}{$\begin{array}{l}\text { Mass } \\
\text { of } \\
\text { Sugar } \\
\text { (g) }\end{array}$} & \multirow[b]{2}{*}{$\begin{array}{l}\text { Mass } \\
\text { of Milk } \\
\quad(\mathrm{g})\end{array}$} & \multirow{2}{*}{$\begin{array}{c}\text { Titratable } \\
\text { acidity (g } \\
\text { lactic } \\
\text { acid/100g) } \\
\left(Y_{1}\right)\end{array}$} & \multirow[b]{2}{*}{$\begin{array}{l}\text { SDE (brix) } \\
\quad\left(Y_{2}\right)\end{array}$} & \multirow[b]{2}{*}{$\begin{array}{l}\mathrm{Ph} \\
\left(Y_{3}\right)\end{array}$} & \multirow[b]{2}{*}{$\begin{array}{c}\text { Ash (\%) } \\
\left(Y_{4}\right)\end{array}$} & \multirow[b]{2}{*}{$\begin{array}{l}\text { Viscosity } \\
\qquad(\mathrm{cp}) \\
\left(Y_{5}\right)\end{array}$} & \multicolumn{3}{|c|}{ Color } \\
\hline & & & & & & & & & $\begin{array}{l}\text { TC } \\
\left(Y_{6}\right)\end{array}$ & $\begin{array}{c}\mathrm{H} \\
\left(Y_{7}\right)\end{array}$ & $\begin{array}{l}\text { WI } \\
\left(Y_{8}\right)\end{array}$ \\
\hline 1 & 5.0 & 50.0 & 70.0 & $0.74 \pm 0.02$ & $16.6 \pm 0.50$ & $4.69 \pm 0.005$ & $0.22 \pm 0.00$ & $38.76 \pm 0.66$ & $85.43 \pm 0.05$ & $120.31 \pm 0.25$ & $81.27 \pm 0.00$ \\
\hline 2 & 5.0 & 75.0 & 70.0 & $0.75 \pm 0.00$ & $16.65 \pm 0.65$ & $4.67 \pm 0.005$ & $0.54 \pm 0.00$ & $39.69 \pm 0.54$ & $85.20 \pm 0.10$ & $120.13 \pm 0.26$ & $81.01 \pm 0.02$ \\
\hline 3 & 5.0 & 62.5 & 120.0 & $1.13 \pm 0.02$ & $22.45 \pm 0.05$ & $4.88 \pm 0.01$ & $0.94 \pm 0.00$ & $200.17 \pm 0.46$ & $91.82 \pm 0.02$ & $101.83 \pm 0.04$ & $81.97 \pm 0.01$ \\
\hline 4 & 5.0 & 62.5 & 20.0 & $0.45 \pm 0.00$ & $11.90 \pm 0.10$ & $4.47 \pm 0.005$ & $0.06 \pm 0.00$ & $288.68 \pm 0.57$ & $81.92 \pm 0.01$ & $109.89 \pm 0.00$ & $79.87 \pm 0.01$ \\
\hline 5 & 3.5 & 62.5 & 70.0 & $0.63 \pm 0.02$ & $17.45 \pm 0.35$ & $4.57 \pm 0.005$ & $0.99 \pm 0.08$ & $30.21 \pm 0.09$ & $85.46 \pm 0.00$ & $116.83 \pm 0.06$ & $80.47 \pm 0.00$ \\
\hline 6 & 3.5 & 75.0 & 20.0 & $0.49 \pm 0.01$ & $17.95 \pm 0.15$ & $4.39 \pm 0.005$ & $0.77 \pm 0.14$ & $30.53 \pm 0.24$ & $79.50 \pm 0.33$ & $122.67 \pm 0.8$ & $77.17 \pm 0.18$ \\
\hline 7 & 3.5 & 75.0 & 120.0 & $1.17 \pm 0.00$ & $23.55 \pm 0.25$ & $4.69 \pm 0.005$ & $1.23 \pm 0.14$ & $109.67 \pm 0.33$ & $81.27 \pm 0.00$ & $103.43 \pm 0.02$ & $81.74 \pm 0.00$ \\
\hline 8 & 3.5 & 62.5 & 70.0 & $0.81 \pm 0.01$ & $17.45 \pm 0.50$ & $4.61 \pm 0.005$ & $1.01 \pm 0.05$ & $176.23 \pm 0.87$ & $89.84 \pm 0.00$ & $109.86 \pm 0.03$ & $80.43 \pm 0.01$ \\
\hline 9 & 3.5 & 50.0 & 20.0 & $0.50 \pm 0.00$ & $12.70 \pm 0.00$ & $4.45 \pm 0.005$ & $0.75 \pm 0.00$ & $219.87 \pm 0.84$ & $88.27 \pm 0.01$ & $109.44 \pm 0.03$ & $78.64 \pm 0.00$ \\
\hline 10 & 3.5 & 62.5 & 70.0 & $0.80 \pm 0.00$ & $21.40 \pm 0.15$ & $4.66 \pm 0.005$ & $0.99 \pm 0.02$ & $267.89 \pm 0.56$ & $80.36 \pm 0.01$ & $103.10 \pm 0.05$ & $81.77 \pm 0.00$ \\
\hline 11 & 3.5 & 50.0 & 120.0 & $1.21 \pm 0.00$ & $21.40 \pm 0.35$ & $4.77 \pm 0.01$ & $1.06 \pm 0.04$ & $298.90 \pm 0.17$ & $88.61 \pm 0.01$ & $113.39 \pm 0.04$ & $81.03 \pm 0.00$ \\
\hline 12 & 2.0 & 62.5 & 120.0 & $0.72 \pm 0.00$ & $21.75 \pm 0.15$ & $4.68 \pm 0.00$ & $1.37 \pm 0.01$ & $74.36 \pm 0.08$ & $88.19 \pm 0.20$ & $98.82 \pm 0.43$ & $79.83 \pm 0.06$ \\
\hline 13 & 2.0 & 75.0 & 70.0 & $0.86 \pm 0.00$ & $21.10 \pm 0.10$ & $4.97 \pm 0.005$ & $1.01 \pm 0.02$ & $74.52 \pm 0.16$ & $86.04 \pm 0.01$ & $109.37 \pm 0.01$ & $78.42 \pm 0.00$ \\
\hline 14 & 2.0 & 50.0 & 70.0 & $0.68 \pm 0.01$ & $19.15 \pm 0.45$ & $4.80 \pm 0.005$ & $0.97 \pm 0.01$ & $266.16 \pm 1.07$ & $83.21 \pm 0.00$ & $104.87 \pm 0.02$ & $79.58 \pm 0.01$ \\
\hline 15 & 2.0 & 62.5 & 20.0 & $0.51 \pm 0.01$ & $15.65 \pm 0.05$ & $4.88 \pm 0.01$ & $0.86 \pm 0.02$ & $296.04 \pm 0.23$ & $81.07 \pm 0.01$ & $113.78 \pm 0.01$ & $77.10 \pm 0.00$ \\
\hline
\end{tabular}

Note: $Y_{1}$ (Soluble dry extracts), $Y_{2}$ (titratable acidity), $Y_{3}(\mathrm{pH}), Y_{4}$ (ashes), $Y_{5}$ (viscosity), $Y_{6}$ (total color), $Y_{7}$ (angle h), $Y_{8}$ (whiteness index). DSE (dry soluble extract), gram (g).

of the parameters studied. The results obtained from the ANOVA are shown in Table 3. $\mathrm{R}^{2}$ Values range from $42.63 \%$ to $98.18 \%$ and was established in Table 3. Responses on witch factor have global significant effects (linear, interaction, or quadratic) are marked $\left({ }^{*}\right)$ (Table 3$)$. The p-values below 0.05 indicate that the quadratic model of the yoghurt formulation is statistically significant at a $95 \%$ confidence interval. Titratable acidity, soluble dry extract, $\mathrm{pH}$, ash, viscosity, total color, hue, and whiteness index are described respectively by $Y_{1}, Y_{2}, Y_{3}, Y_{4}$, $Y_{5}, Y_{6}, Y_{7}$ and $Y_{8}$ which are regression equation predicting the relationship between the factors (Table 4).

\section{5) Titratable acidity}

Titratable acidity is a very important factor in the characterization and acceptability of fermented dairy products. The variance analysis of the regression models gives a $\mathrm{R}^{2}$ value of $90.67 \%$. The titratable acidity varies from $0.45 \%$ to $1.21 \%$. Response surface plot of the relationship is shown as Figure 3 . The effect of independent variables is represented in Figure 4. The high value is found in formulation ( $3.5 \mathrm{l} ; 50 \mathrm{~g} ; 120 \mathrm{~g}$ ) and the lowest value in formulation ( $5 \mathrm{l} ; 62.5 \mathrm{~g}$; $20 \mathrm{~g}$ ). The linear factor milk powder mass is the only one to have the most influence on the acidity of yogurts, with significant positive effects $(\mathrm{p}<0.05)$ (Figure 4). The larger the milk powder mass, the greater the effects on the titratable acidity. Milk is the main element used by lactic acid bacteria during 
Table 3. ANOVA for the experimental variables.

\begin{tabular}{ccccccccc}
\hline Model & Titratable Acidity & $\begin{array}{c}\text { Soluble Dry } \\
\text { Extracts }\end{array}$ & pH & ASH & Viscosity & TC & H & WI \\
\hline Transformation & None & None & None & None & None & None & None & None \\
D.D.L. Model & 9 & 9 & 9 & 9 & 9 & 9 & 9 & 9 \\
Probability & $0.0390^{*}$ & 0.0869 & 0.0511 & $0.0028^{*}$ & 0.7665 & 0.8823 & 0.3170 & $0.0008^{*}$ \\
D.D.L. error & 5 & 5 & 5 & 5 & 5 & 5 & 5 & 5 \\
Standard error & 0.125632 & 2.06723 & 0.0901018 & 0.101923 & 125.447 & 4.63919 & 6.22152 & 0.334627 \\
Mean absolute error & 0.062222 & 1.03444 & 0.0432222 & 0.0487778 & 60.9667 & 2.983 & 2.32433 & 0.156333 \\
R-squared & 90.67 & 86.57 & 89.47 & 96.95 & 51.63 & 42.63 & 74.11 & 98.18 \\
Adjusted & 73.88 & 62.38 & 70.51 & 91.47 & 0.00 & 0.00 & 27.50 & 94.90 \\
R-squared & & & & & & & &
\end{tabular}

*Significant at 0.05 .

Table 4. Equation of regression of response.

\begin{tabular}{|c|c|c|}
\hline$Y_{1}$ & $\begin{aligned} Y_{1}= & 1.58198+0.257926 X_{1}-0.05016 X_{2}-0.000177 X_{3}-0.028704 X_{1}^{2}+0.000483 X_{2}^{2} \\
& +0.000008 X_{3}^{2}-0.002267 X_{1} X_{2}+0.00156667 X_{1} X_{3}-0.000012 X_{2} X_{3}\end{aligned}$ & (3) \\
\hline$Y_{2}$ & $\begin{aligned} Y_{2}= & 16.6632+2.67398 X_{1}-0.318867 X_{2}+0.085675 X_{3}-0.500926 X_{1}^{2}-0.0253333 X_{1} X_{2} \\
& +0.0268333 X_{1} X_{3}+0.00470667 X_{2}^{2}-0.00124 X_{2} X_{3}-0.000240833 X_{3}^{2}\end{aligned}$ & (4) \\
\hline$Y_{3}$ & $\begin{aligned} Y_{3}= & 5.54418-0.536037 X_{1}+0.00286 X_{2}-0.00192833 X_{3}+0.0714815 X_{1}^{2}+0.000053 X_{2}^{2} \\
& -0.000019 X_{3}^{2}-0.002533 X_{1} X_{2}+0.00203 X_{1} X_{3}-0.000008 X_{2} X_{3}\end{aligned}$ & (5) \\
\hline$Y_{4}$ & $\begin{aligned} Y_{4}= & -0.878881+0.186537 X_{1}+0.0549 X_{2}-0.00486 X_{3}-0.101481 X_{1}^{2}+0.00373333 X_{1} X_{2} \\
& +0.001233 X_{1} X_{3}-0.000533 X_{2}^{2}+0.00006 X_{2} X_{3}+0.000016 X_{3}^{2}\end{aligned}$ & (6) \\
\hline$Y_{5}$ & $\begin{aligned} Y_{5}= & 66.0527-198.462 X_{1}+26.6765 X_{2}-5.203 X_{3}-0.723889 X_{1}^{2}+2.5676 X_{1} X_{2} \\
& +0.4439 X_{1} X_{3}-0.330872 X_{2}^{2}+0.000044 X_{2} X_{3}+0.0233325 X_{3}^{2}\end{aligned}$ & (7) \\
\hline$Y_{6}$ & $\begin{aligned} Y_{6}= & 60.0084+1.218 X_{1}+0.815993 X_{2}-0.00922833 X_{3}+0.115 X_{1}^{2}-0.0354667 X_{1} X_{2} \\
& +0.00926667 X_{1} X_{3}-0.006904 X_{2}^{2}+0.000572 X_{2} X_{3}-0.0000795 X_{3}^{2}\end{aligned}$ & (8) \\
\hline$Y_{7}$ & $\begin{aligned} Y_{7}= & 167.815+8.15278 X_{1}-3.01338 X_{2}+0.551525 X_{3}-0.536111 X_{1}^{2}+0.031656 X_{2}^{2} \\
& -0.0010575 X_{3}^{2}-0.0624 X_{1} X_{2}+0.023 X_{1} X_{3}-0.009276 X_{2} X_{3}\end{aligned}$ & (9) \\
\hline$Y_{8}$ & $\begin{aligned} Y_{8}= & 74.6532+0.2445 X_{1}+0.11616 X_{2}-0.005905 X_{3}-0.011667 X_{1}^{2}-0.002072 X_{2}^{2} \\
& -0.000281 X_{3}^{2}+0.012 X_{1} X_{2}-0.0021 X_{1} X_{3}+0.001272 X_{2} X_{3}\end{aligned}$ & (10) \\
\hline
\end{tabular}

${ }^{*}$ Co-efficient are significant $(\mathrm{p}<0.05)$.

fermentation and therefore in the production of lactic acid and acidic compounds. As such, it plays a key role in the acidity of yogurts. The lactose contained milk is an ideal substrate for yogurt cultures. These microorganisms use milk lactose to release more lactic acid, which leads to the influence of milk on acidity. Similar results were found by [18], it was found that the addition of sodium caiseinate increased the acidity of fermented tigernut. The acidic compounds of yoghurt are intermediates of several metabolic processes that 


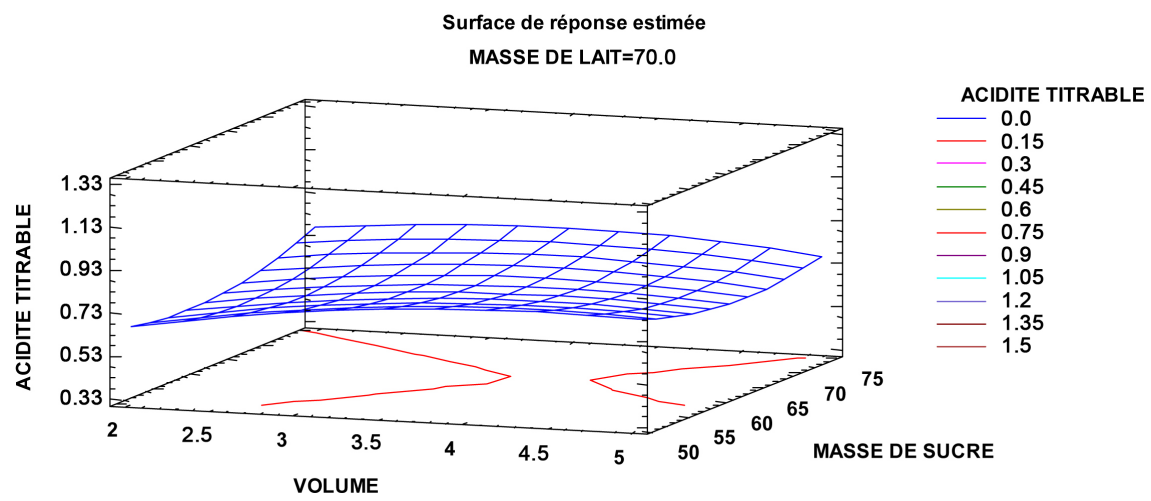

Figure 3. Titratable acidity response surface.

Graphique de Pareto standardisé pour ACIDITE TITRABLE

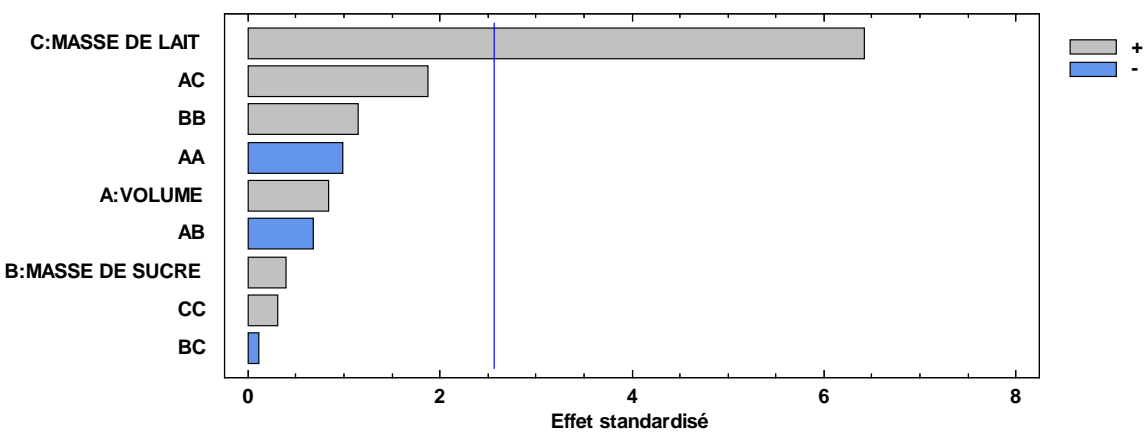

Figure 4. Pareto graph of the effects on titratable acidity.

influence the shelf life. However, given the fiber content of the tiger nut milk, it has been reported that the hydrolysis of these compound during the fermentation could increase glucose and maltose levels, which are converted into organic acids or alcohols by microbial activity and which directly influences the acidity of the environment [19]. On the other hand, $\mathrm{pH}$ and acidity can be affected by several factors such as the initial microbial load of milk, milk and handling hygiene conditions [20] but also the amount and type of materials solid, culture activity and fermentation period [21]. As for the volume of tiger nut milk, it has very little influence on the lactic acid content ( $\mathrm{p}>0.05)$. The less the volume of tiger nut milk is concentrated, the lower the lactic acid content, because the tiger nut milk itself has a low lactic acidity of the order of $0.15 \%$ [22]. Interactions between milk nutmeg and milk powder, and sugar interactions, are also important but not significant ( $p>0.05$ ). The co-efficient of determination predicting the mean score for aroma explained up to $92.41 \%$ (Table 3 ) variability in data. The regression Equation (3) predicting the relationship between titratable acidity and independent variables is established in Table 4.

\section{6) Soluble dry extract}

ANOVA indicates an $\mathrm{R}^{2}$ equal to $86.58 \%$ on the variability of soluble solids content. Its adjusted $\mathrm{R}^{2}$ is $62.38 \%$. The various yogurt samples have dry soluble extract contents ranging between $11.90 \%$ to $23.55 \%$. However, the milk powder 
mass remains the only factor with a significant $(\mathrm{p}<0.05)$ positive influence on the dry soluble extract content. Nevertheless, the linear factor of the sugar mass and the interaction between the volume and the mass of powdered milk and the concentration of the tiger nut milk have less significant $(p>005)$ but positive effects. A visual illustration of the relationship is shown in Figure 5 and its mathematical relationship expressed in Equation (4) is established in Table 4. The high value of soluble dry extract is found in formulation (3.5 l; $75 \mathrm{~g} ; 120 \mathrm{~g}$ ) and the lowest value in formulation $(5 \mathrm{l} ; 62.5 \mathrm{~g} ; 20 \mathrm{~g})$. The higher the milk powder mass, the higher the soluble solids content. Tiger nut milk dry soluble extract would be important the more the volume is important because of the insolubility of certain compounds. If the milk is highly concentrated, it cannot extract the maximum of soluble compounds and the process can increase the amount of insoluble compounds [18]. From the foregoing, it is apparent that the amount of dry soluble extract of a sample is correlated with the quantities of milk powder, sugar and the concentration of milk (Figure 6). These results would be due to as much to the milk used to bacteriological activities. The milk used during the formulation is instant milk powder, thus containing a high content of soluble solids. As for lactic acid bacteria, the lactic acid they produce during fermentation is an organic acid that preserves and concentrates the dry matter of milk.

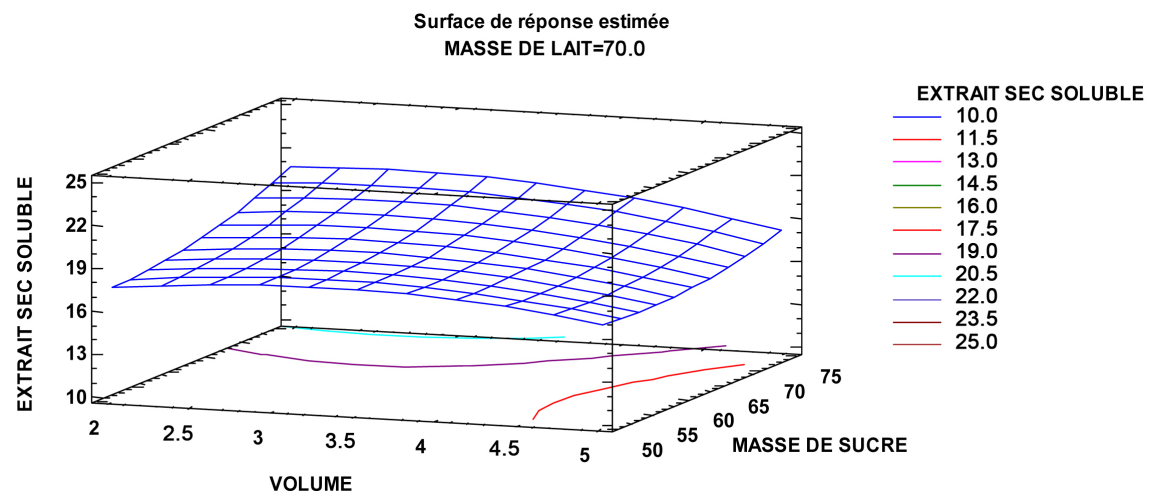

Figure 5. Soluble dry extract response surface plot.

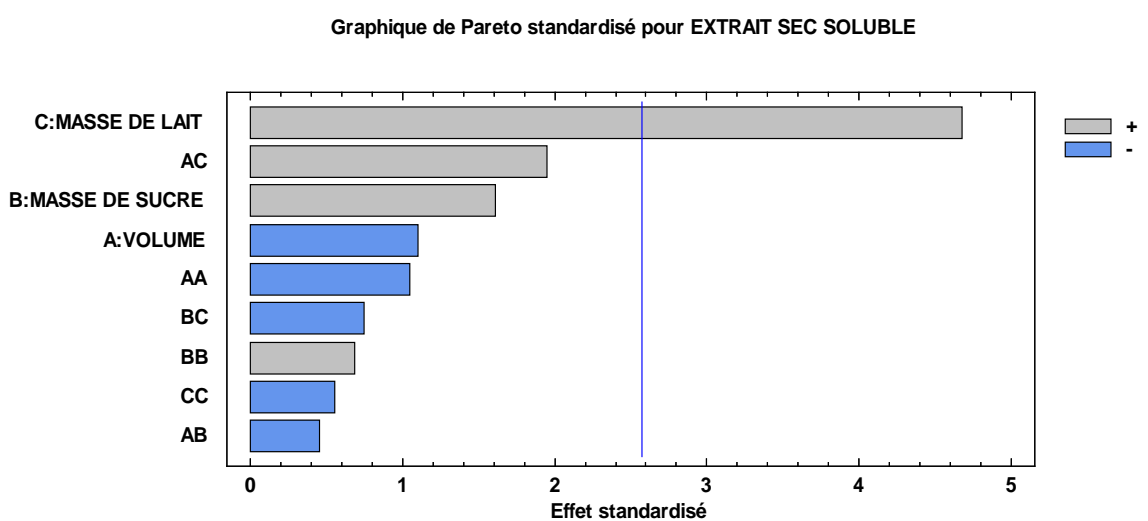

Figure 6. Pareto graph of the effects on soluble dry extract. 


\section{7) $\mathrm{pH}$}

Using a multiple regression analysis of the experimental results, the $\mathrm{pH}$ is obtained by the second-order polynomial Equation (5) (Table 4) which describes the interaction between the three independents factors. The analysis of variance of the coefficient of determination $\mathrm{R}^{2}$ indicates that the model accounts for $89.47 \%$ of the $\mathrm{pH}$ variability. The adjusted R-squared is $70.51 \%$. A visual illustration of $\mathrm{pH}$ relationship with idependent wariables is shown in Figure 7 and its mathematical relationship expressed in Equation (5) is established in Table 4. The effects of the quadratic factors of the concentration of the tiger nut milk and the interaction factors of the concentration of the tiger nut milk and the milk powder mass positively and significantly $(\mathrm{p}<0.05)$ affect the yogurt $\mathrm{pH}$ (Figure 8). The effect of the sugar mass was not significant $(\mathrm{P}>0.05)$ on the $\mathrm{pH}$ value (Figure 8). The $\mathrm{pH}$ of the various tiger nut yogurts varies from 4.39 to 4.97. The highest value was recorded in formulation ( 2 l; $75 \mathrm{~g} ; 70 \mathrm{~g})$ while the formulation $(3.5 \mathrm{l} ; 75 \mathrm{~g} ; 20 \mathrm{~g}$ ) had the lowest $\mathrm{pH}$. The tiger nut milk is very little acid but during fermentable combined with milk powder, the production of lactic acid intensifies, the medium acidifies where the $\mathrm{pH}$ drop to values around 4. These results are on the other hand below those of [23], for yoghurt based on

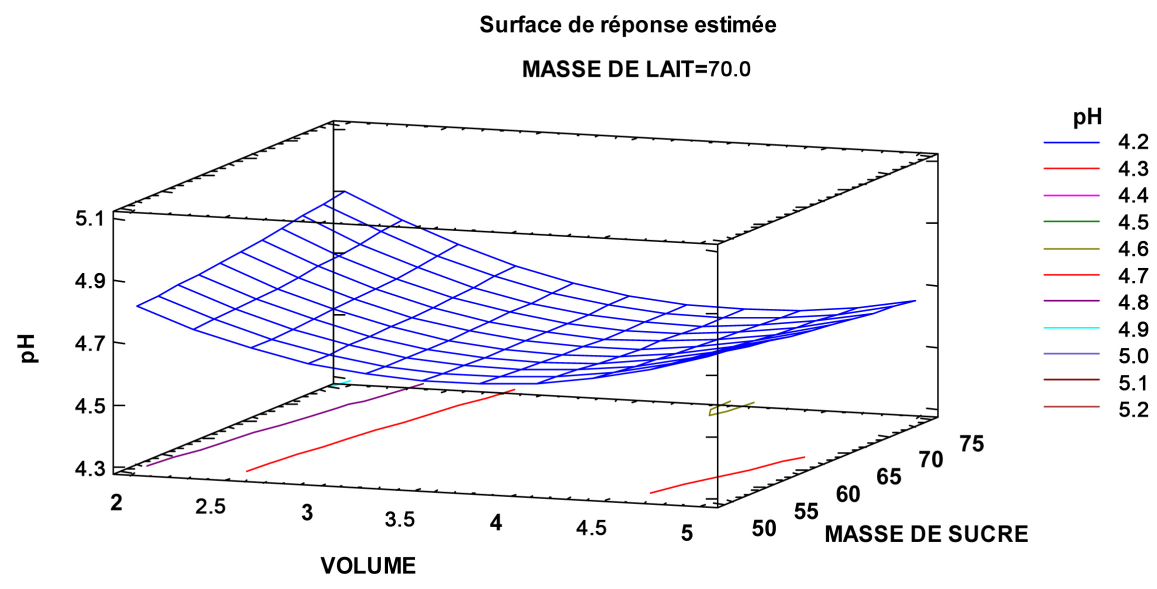

Figure 7. $\mathrm{pH}$ response surface.

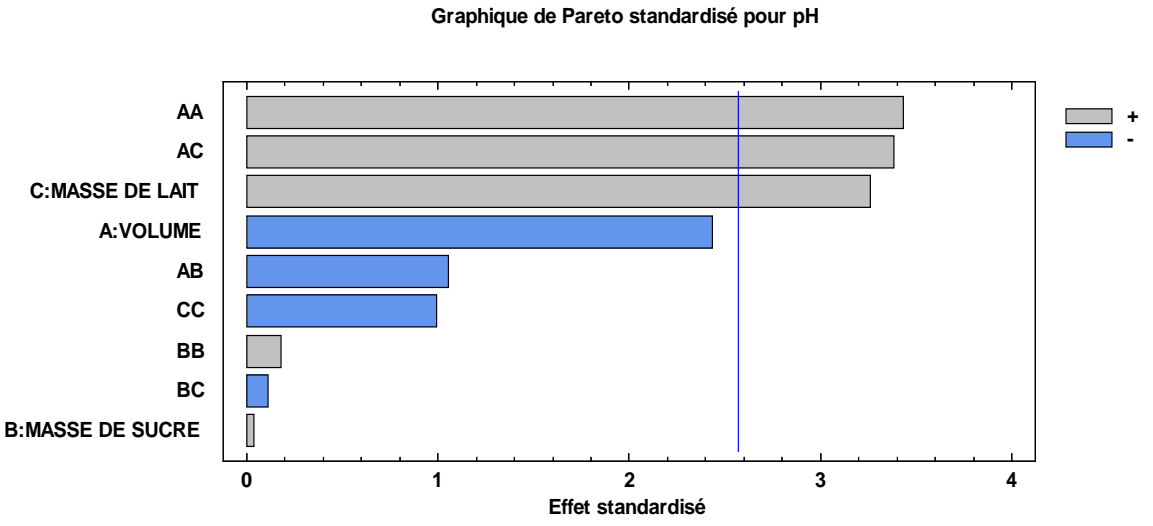

Figure 8. Pareto graph of the effects on the $\mathrm{pH}$. 
pure yellow tiger nut with a $\mathrm{pH}$ equal to 6.10, yoghurt mixed yam and soybean for a $\mathrm{pH} 6.32$ and yoghurt mixed soya and coconut of $\mathrm{pH}$ 6.58. These reported $\mathrm{pH}$ values are dependent on tiger nut milk which has a $\mathrm{pH}$ of plus or minus 6.6 [22]. The $\mathrm{pH}$ is an essential factor for dairy products such as yoghurt; it plays a large role in consumer acceptance of the product and good microbiological quality. A non-standard $\mathrm{pH}$ would result in a finished product unfit for consumption. The values reported during this experiment are therefore acceptable and thus demonstrate compliance with the various manufacturing steps: pasteurization, incubation time and sufficient lactic ferments, to reach the appropriate $\mathrm{pH}$.

\section{8) Ash}

Analysis of variance (ANOVA) of the $\mathrm{R}^{2}$ indicates that the model accounts for 96.95\% (Table 3 ) of the ash rate variability. The results of analysis carried out, reveal that the total ash content of yoghurt ranges from $0.06 \%$ to $1.37 \%$. The highest value of $1.37 \%$ was found in formulation (3.5 l; $75 \mathrm{~g} ; 120 \mathrm{~g}$ ) while the lowest value was found in formulation ( $5 \mathrm{l} ; 62.5 \mathrm{~g} ; 20 \mathrm{~g}$ ) (Table 2). These values are moderately higher than those found by [24] Chukwuma et al. (2016), for yoghurts made from pure sapling $(0.43 \%)$, coconut $(0.36 \%)$, cow's milk $(0.73 \%)$ and coconut mix and tiger nut $(0.68 \%)$. The interaction of the variables of the formulation is described in the following three-dimensional response surface (Figure 9) and the mathematical function (Equation (6)) was the best to describe the relationship between the ashes and the factors and (Table 4 ). The results show that milk mass $(\mathrm{p}<0.05)$, volume $(\mathrm{p}<0.05)$ and the effect of quadratic factors of volume $(\mathrm{p}<0.05)$ are significant variables (Figure 10$)$. The effect of the sugar mass is not significant $(\mathrm{p}>0.05)$ (Figure 10) on the ash content. The ash rate could be important when the tiger nut is concentrated in addition to the milk supply. Factors with a significant influence $(p<0.05)$ on the ash content of the samples are the volume of tiger nut milk, which has a negative impact, inversely proportional to the ash content, as well as its interactions and milk powder mass, which has a positive impact. It has been found that the mass of ash increases with the elevation of the mass of milk.

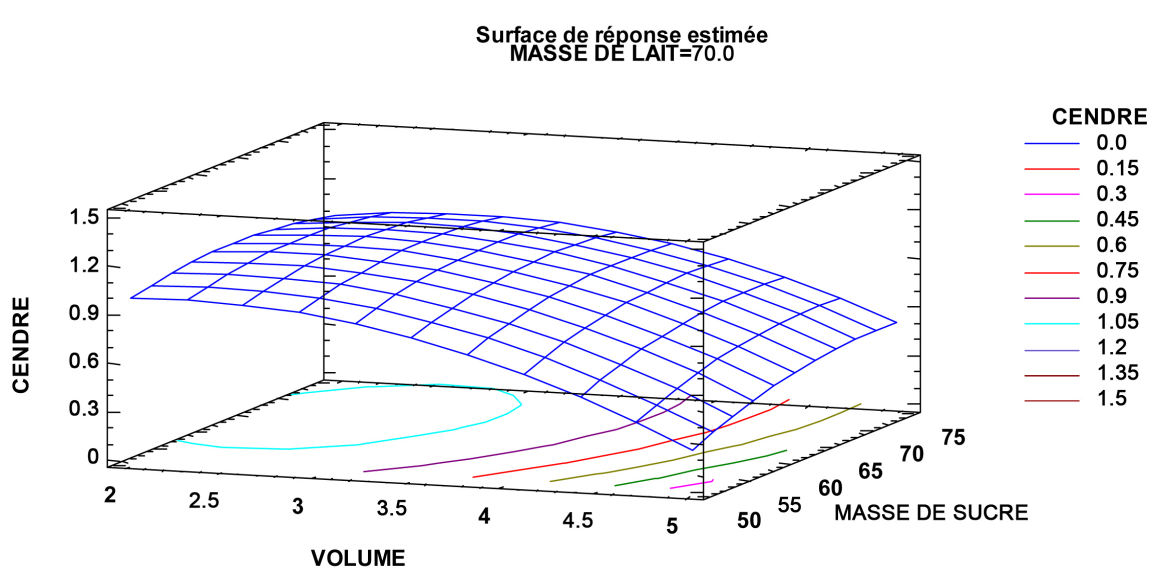

Figure 9. Ash content response surface. 


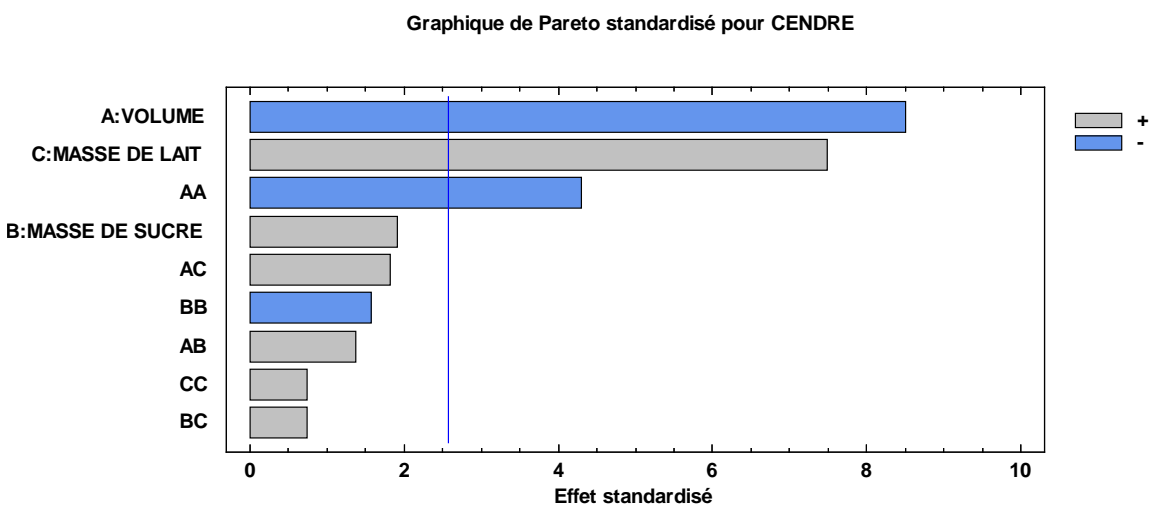

Figure 10. Pareto graph of the effects on the ash content.

\section{9) Viscosity}

The $\mathrm{R}^{2}$ statistic analysis indicates that the model explains $51.6314 \%$ of the variability of the viscosity. Values reported for viscosity range from 296.04 to $30.21 \mathrm{Cp}$. A visual illustration of the relationship between the viscosity and independent variables is shown in Figure 11 and its mathematical relationship expressed in Equation (7) is established in Table 4. These are influenced mainly by the sugar mass and milk powder interactions, although not significant ( $\mathrm{p}>$ 0.05 ) (Figure 12). The mass of sugar has a negative influence on the viscosity of yogurts. The more it increases and the less yoghurt is viscous. Indeed, lactic acid bacteria proliferate at $45^{\circ} \mathrm{C}$ and metabolize sugars to acids. This increased acidity causes denaturation of the proteins and forms a gel resulting from the viscous nature characteristic of yogurts. However, a high sugar intake in yogurt would contribute to the proliferation of acidic compounds and thus to a drop in viscosity. The low protein yogurts tend to have low viscosity because of the low water retention capacity of coagulum. These variations in viscosity could be explained by the protein rearrangements that take place where the protein-protein interactions are favored by the low energy bonds, which would lead to an increase in viscosity [25]. As a result, the gel network is even more important that the proportion of protein in yogurt is important. Also, the degradation of lactose into lactic acid leads to a drop in $\mathrm{pH}$ then gelling the medium with irreversible changes [26]. Similarly, proteolysis of caseins is induced during technological processes by the addition of lactic acid bacteria producing their proteases. This phenomenon brings about changes in the viscosity of the product and in the consistency with the production of amino acids and peptides. However, for some tests, huge differences in values could be observed. These differences could be attributed not only to the imprecise amounts of ferments incorporated during production. Similarly, during heat treatments, a complex between casein and protein is formed, but the degree of formation of this complex depends on the temperature and the treatment time, as well as the amount of whey protein present in the whey protein milk [27]. The formation of this complex has an influence on the hydrophilic and hydration properties of the casein micelle and therefore on the rheological properties of yoghurt, in 


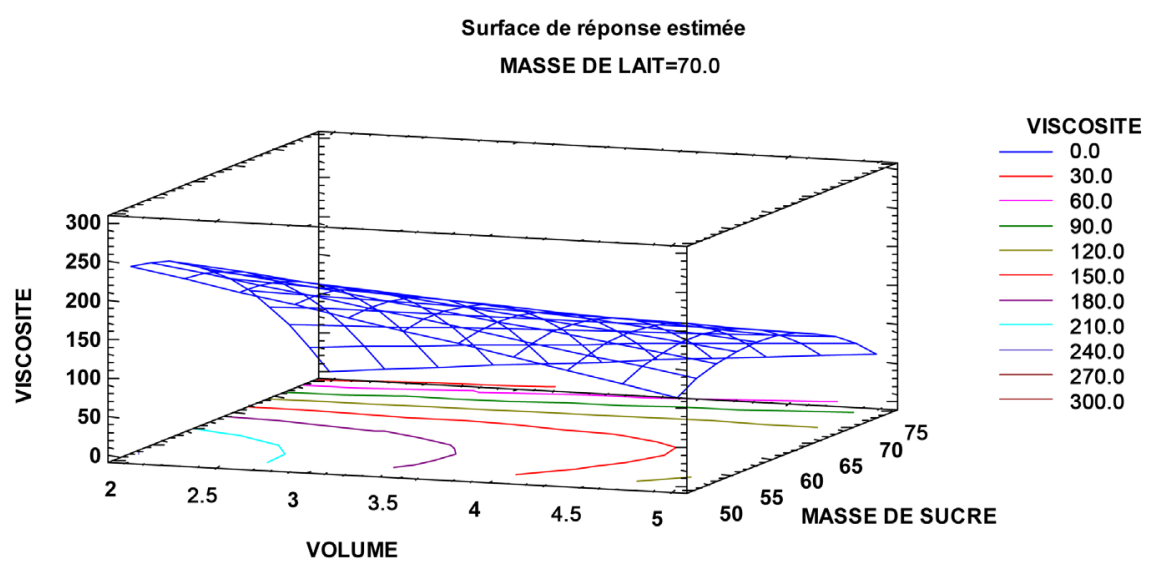

Figure 11. Viscosity response surface.

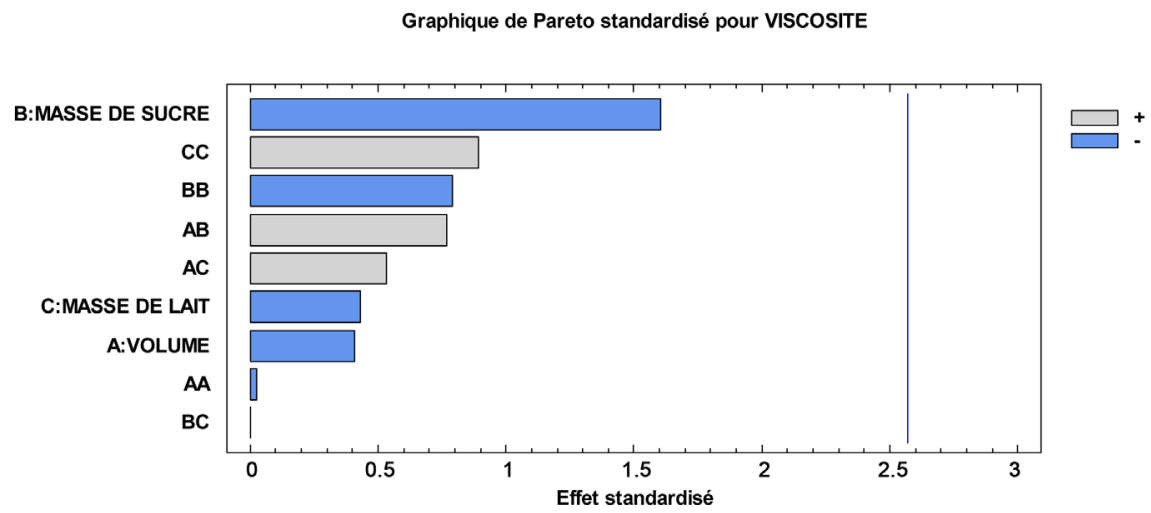

Figure 12. Pareto graph for the viscosity.

particular its viscosity.

\section{0) Color parameters}

In food science, color is one of the main assets of a product that can lead to the purchase by the consumer [28]. It is an important parameter in the making and sometimes tracking of certain products. It can be used as a quality control parameter during storage and its degradation can be attributed to possible reactions. Indeed, different sub-parameters fall into the measure of the color such as the $\mathrm{h}$ angle, the chromacy $\mathrm{c}$ and the variables $a^{\star}$ (green to red), $b^{\star}$ (blue to yellow), $L^{\star}$ or clarity (black to white) which make it possible to calculate the total color TC and the whiteness index WI.

\section{1) Total color}

The analysis results give total color values ranging from 79.5 to 91,82 . These observed variations can be attributed to different opacity levels, related to the level of aggregation of particles. The high value is found in formulation (3.5 1; 50 $\mathrm{g} ; 120 \mathrm{~g})$ and the lowest value in formulation $(3.5 \mathrm{l} ; 75 \mathrm{~g} ; 20 \mathrm{~g})$. The co-efficient of determination predicting the mean score for total color explained up to $42.63 \%$ (Table 3) variability in data. The regression Equation (8) predicting the relationship between total color and process variables is established in Table 4 and the response surface is rrepresented by Figure 13. The higher the brightness 


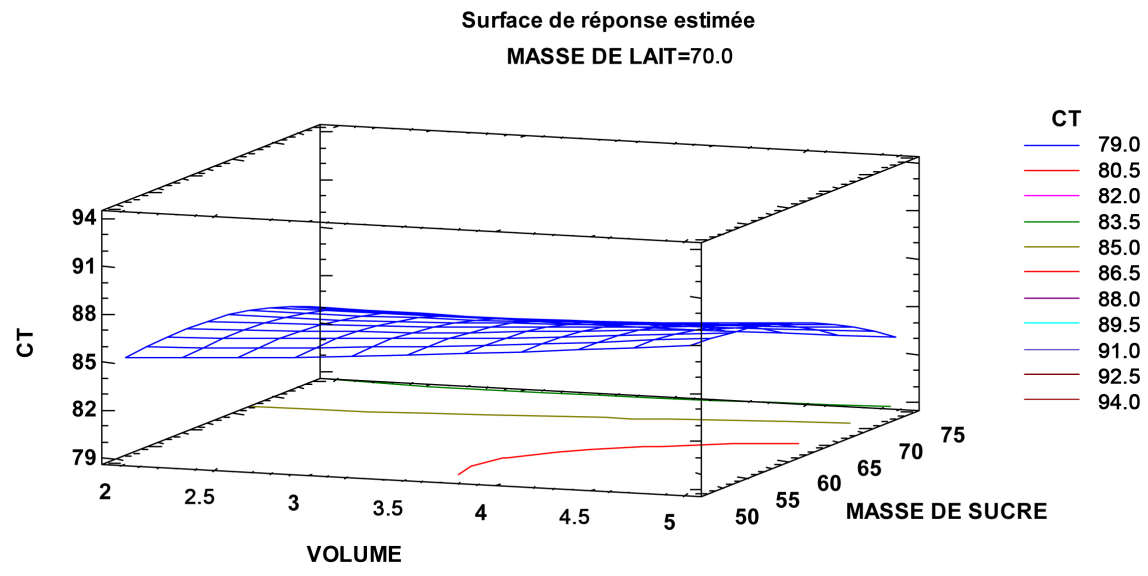

Figure 13. Surface response for the total color.

values, the higher the opacity, the lower the chromium, which also corresponds to a higher brightness index. No factors had a significant influence on the total yoghurt color $(p>0.05)$ (Table 3$)$. However, the total color of the samples predominate when the mass of milk powder increases and the tiger nut dilution (Figure 14). The results of analysis obtained are in agreement with those of [29], who studied color change as affected by the addition of casein. The addition of proteins significantly affected the yoghurt color. As a result, high milk powder content would mean high milk protein content and thus better protein coagulation. Protein coagulation affects the structure and surface properties of yoghurt and improves the absorption of light [30].

\section{2) Hue tint angle}

Statistical analysis of the coefficient of determination $\mathrm{R}^{2}$ indicates that the model accounts for $74.11 \%$ of the variability of Hue. The adjusted $\mathrm{R}^{2}$ is $27.50 \%$. The regression Equation (9) predicted the relationship between Hue value and independent variables is established in Table $4 . \mathrm{H}$ value increase with increasing the tiger volume obtain for on kilogram of tuber and decrease with the milk mass (Figure 15). No factor has a significant effect (Figure 16). However, the effects of the linear and interaction factors are much more pronounced ( $\mathrm{p}<$ 0.05) on the H-hue angle but negative. On the other hand, the linear factor of the tiger nut volume and the quadratic factor of the sugar mass have insignificant influence but positive effects on the hue angle.

\section{3) Whiteness index (WI)}

The whiteness index (WI), which measures the overall whiteness of the food product or its deviation from the white color, ranges from 77.10 to 81.97 (Table 2). Variance analysis of the coefficient of determination R2 indicates that the model explains $98.18 \%$ of the variability of WI however the adjusted R2 is 94.90\%. The regression Equation (10) predicting the relationship between whiteness and process variables is established in Table 4 and the interaction of the variables of the formulation is described by the three-dimensional response surface in Figure 17. The high value of WI is obtained in the formulation (5 l, 
Graphique de Pareto standardisé pour CT

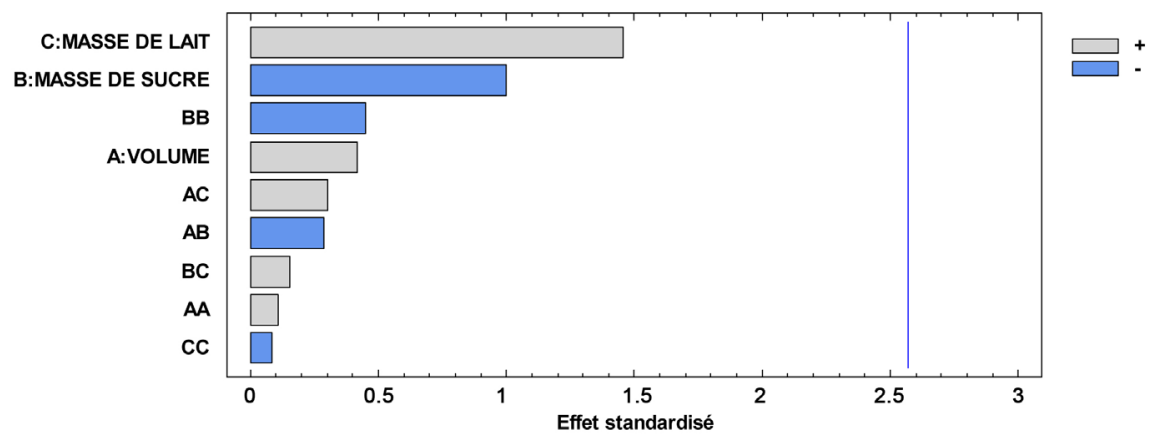

Figure 14. Pareto graph for the total color.

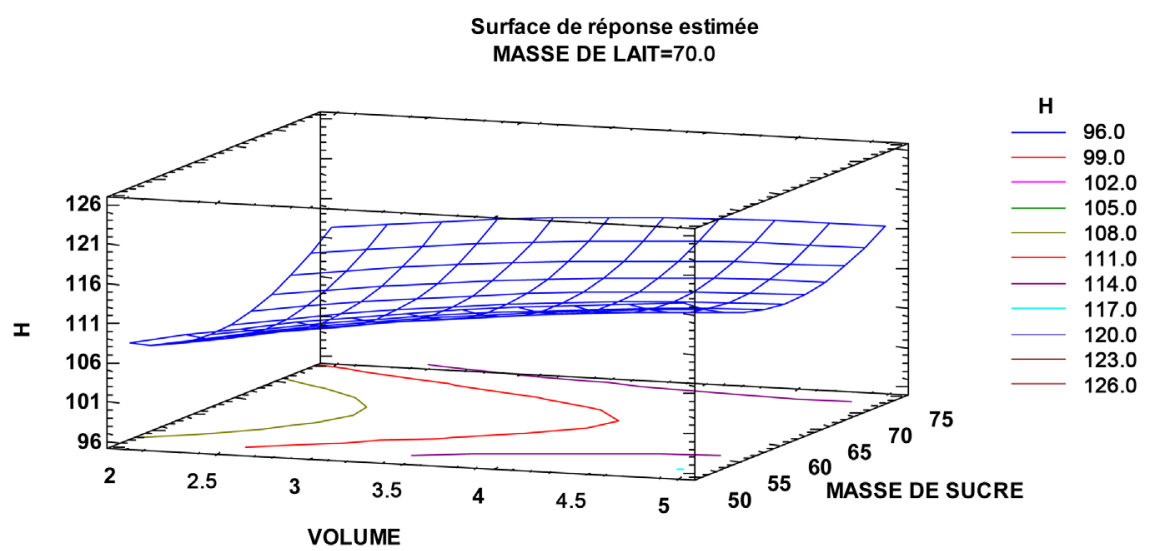

Figure 15. Hue angle response surface.

Graphique de Pareto standardisé pour H

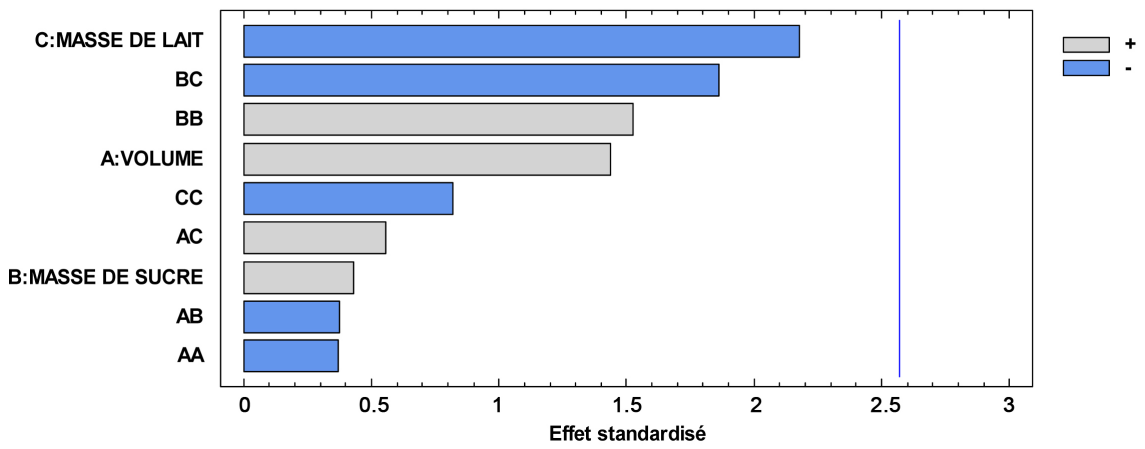

Figure 16. Pareto graph for the hue angle.

$62.5 \mathrm{~g}$ and $120 \mathrm{~g}$ ) and the low respectively for tiger nut volume, sugar mass and milk mass. The linear factors of milk mass ( $<<0.001)$, and of tiger nut milk volume (concentration) $(\mathrm{p}<0.0001)$ are the most factors witch have the most significant effect, the interactive factor of sugar and milk masses $(\mathrm{p}<0.05)$ and the quadratic factor of the milk mass have significant influences on the whiteness index of yogurts (Figure 18). The increase in volume (concentration) causes a highly significant increase in bleaching index (Figure 17). WI is closely related 


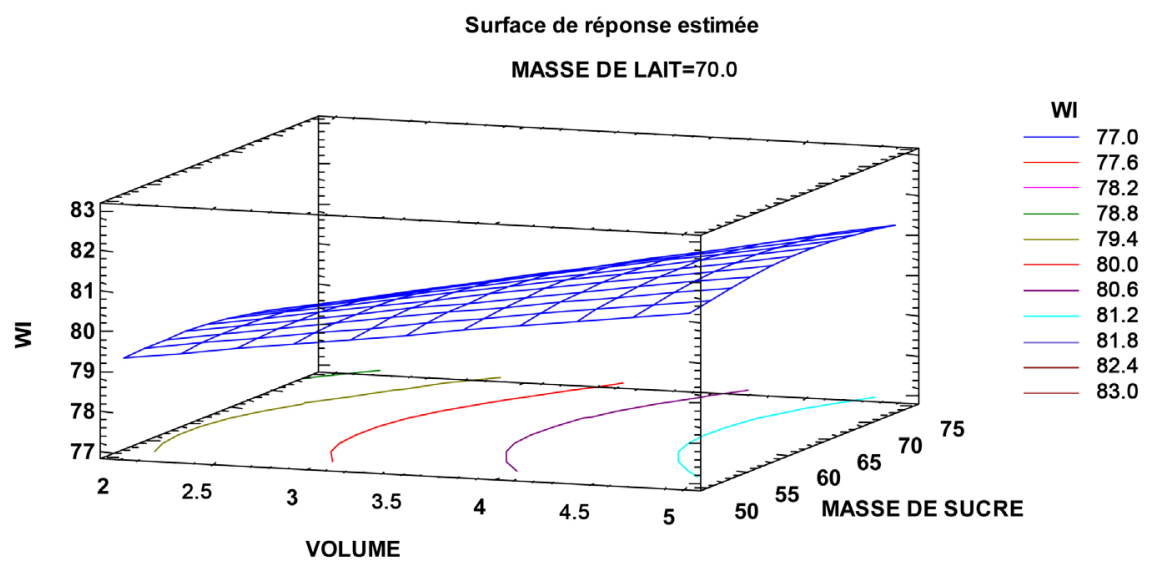

Figure 17. WI response surface.

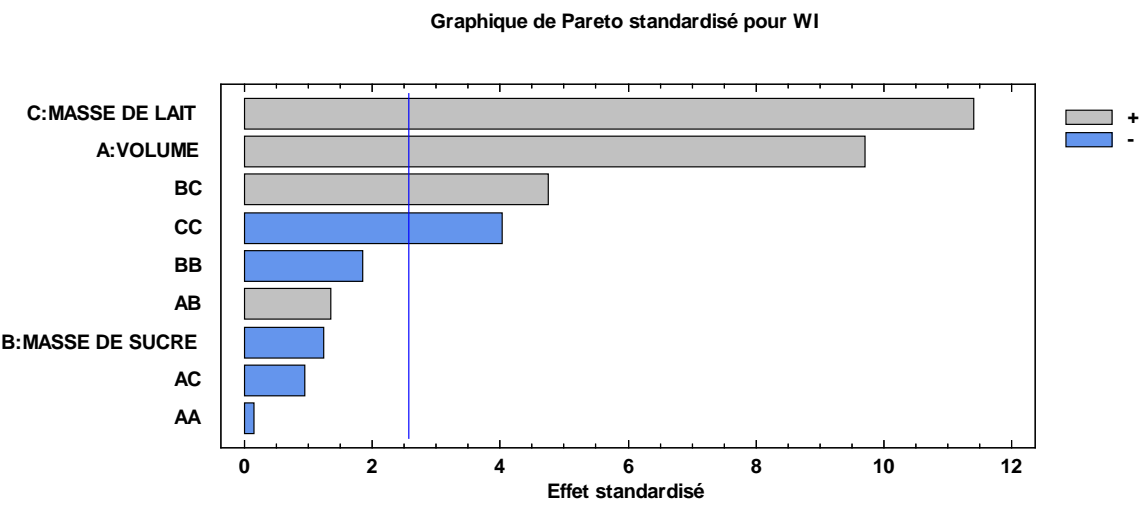

Figure 18. Pareto graph of the index WI.

to brightness $\mathrm{L}$. A high value of $\mathrm{L}$ in the case of yogurt is a good quality factor however a drop in $\mathrm{L}$ can be attributed to color degradation [31] and can be encouraged by the oil content. The variations in the whiteness index of yogurts are due to the physico-chemical properties of the various components and the pretreatment carried out during production, in particular pasteurization which could cause the gelatinization of the starch contained in the tiger nut milk but also non-enzymatic browning reactions and thus interactions between sugar reducing sugars and milk proteins. It has been found that all values of $a^{*}$ are negative thus revealing the presence of green compounds in yoghurt if it is known that tiger nut contains family B vitamins and certain phytochemicals. These findings were made by [32] and attributed these negative values by the presence of tryptophan, tyrosine and riboflavin.

\section{4) Optimization}

Multi-response optimization of RSM was applied to determine the optimal combination in yoghurt preparation. The optimum formulation predicted by the regression model is the follows: for tiger nut milk volume (3.77 1), for milk mass $(63.84 \mathrm{~g})$ and $75 \mathrm{~g}$ for sugar mass. These conditions were tested and compared to the predicted optimal response. Yoghurt optimal sample were prepared using the derived optimum formulation conditions to check the validity of surface 
Table 5. Optimal values of process variables.

\begin{tabular}{|c|c|c|c|c|c|c|c|}
\hline Factors & $\begin{array}{l}\text { Optimal } \\
\text { value }\end{array}$ & Responses & Desirability & Prevision & $\begin{array}{l}\text { Experimental } \\
\text { measures }\end{array}$ & $\begin{array}{c}\text { Inferior } \\
\text { limit at } \\
95.0 \%\end{array}$ & $\begin{array}{c}\text { Superior } \\
\text { limit at } \\
95.0 \%\end{array}$ \\
\hline \multirow{4}{*}{$\begin{array}{l}\text { Volume } \\
\text { (liter) }\end{array}$} & \multirow{4}{*}{3.77} & $\begin{array}{l}\text { Titrable } \\
\text { acidity }\end{array}$ & 1 & 0.80 & $0.66 \pm 0.06$ & 0.596 & 1.004 \\
\hline & & $\begin{array}{c}\text { Soluble } \\
\text { dry extract }\end{array}$ & 0.739 & 20.03 & $18 \pm 0.1$ & 16.66 & 23.39 \\
\hline & & $\mathrm{pH}$ & 0.625 & 4.59 & $4.5 \pm 0.004$ & 4.44 & 4.74 \\
\hline & & Ash & 0.662 & 0.89 & 1.25 & 0.726 & 1.06 \\
\hline \multirow{2}{*}{$\begin{array}{l}\text { Mass of } \\
\text { powdered } \\
\text { milk (g) }\end{array}$} & \multirow[t]{2}{*}{63.84} & WI & 0.623 & 79.93 & $75.24 \pm 0.003$ & 79.38 & 80.47 \\
\hline & & $\mathrm{H}$ & 0.766 & 117.37 & $115.27 \pm 0.145$ & 107.26 & 127.49 \\
\hline \multirow{2}{*}{$\begin{array}{c}\text { Mass of sugar } \\
\text { (g) }\end{array}$} & \multirow[t]{2}{*}{75.0} & $\mathrm{CT}$ & 0.746 & 82.63 & $80.41 \pm 0.19$ & 75.08 & 90.17 \\
\hline & & Viscosity & 0.886 & 43.17 & 36.4 & -160.87 & 247.23 \\
\hline
\end{tabular}

Table 6. Proximate analysis of optimal yoghurt.

\begin{tabular}{cc}
\hline Parameter $(/ 100 \mathrm{~g})$ & Content \\
\hline Proteins $\%$ & 2.2 \\
Fat $\%$ & 5.67 \\
Calcium $(\mathrm{mg})$ & 160 \\
Magnesium $(\mathrm{mg})$ & 20 \\
Potassium $(\mathrm{mg})$ & 180 \\
\hline
\end{tabular}

response model. The experimental data were compared with predicted values in order to verify adequacy of final reduced flour (Table 5). The overall desirability is $75 \%$ and this shows that is fit to explain this study. The results of the proximate composition of the tiger nut yoghurt are presented in Table 6. Protein and fat content are respectively $2.5 \%$ and $5.67 \%$. Calcium, magnesium and potassium content are respectively are $160 \mathrm{mg}, 40 \mathrm{mg}$ and $180 \mathrm{mg}$ in $100 \mathrm{~g}$ of the optimal yoghurt.

\section{Conclusion}

The response surface methodology has successfully optimized the tiger nut yoghurt formulation process. The experimental data after optimization and the predicted data are significantly the same overall. The development of yoghurt based on tiger nuts by adding milk powder can constitute on the one hand a real nutritional advantage in view of these many biological properties of nutsedge and other departure its valuation. Optimization has made it possible to minimize milk powder intake. The physicochemical and biochemical analysis confirms the nutritional value of the product compared to those already existing on the market. Further studies on microbial quality and stability would predict the 
conditions of optimized product use. Finally, the production, utilization, and consumption of tigernut-based yoghurt should be encouraged because such product will be helpful in providing nutritious, safe and wholesome food for the poor and malnourished populations in developing country.

\section{Conflicts of Interest}

The authors declare no conflicts of interest regarding the publication of this paper.

\section{References}

[1] Yilmaz-Ersan, L. and Kurdal, E. (2014) The Production of Set-Type-Bio-Yoghurt with Commercial Probiotic Culture. International Journal of Chemical Engineering and Applications, 5, 402-408. https://doi.org/10.7763/IJCEA.2014.V5.418

[2] Sengupta, S., Chakraborty, A. and Bhowal, J. (2014) Production and Evaluation of Yogurt with Watermelon (Citrullus lanatus) Juice. Journal of International Academic Research for Multidisciplinary, 2, 249-257.

[3] Aboulfazli, F. and Baba, A.S. (2015) Effect of Vegetable Milk on Survival of Probiotics in Fermented Ice Cream under Gastrointestinal Conditions. Food Science and Technology Research, 21, 391-397. https://doi.org/10.3136/fstr.21.391

[4] Oladele, A.K. and Aina, J.O. (2007) Chemical Composition and Functional Properties of Flour Produced from Two Varieties of Tigernut (Cyperus esculentus). African Journal of Biotechnology, 6, 2473-2476. https://doi.org/10.5897/AJB2007.000-2391

[5] Shaker, M.A., Ahmed , M.G., Amany, M.B. and Shereen, L.N. (2009) Chufa Tubers (Cyperus esculentus L.): As a New Source of Food. World Applied Sciences Journal, 7, 151-156.

[6] Emurotu, J.E. (2017) Comparison of the Nutritive Value of the Yellow and Brown Varieties of Tiger Nut. IOSR Journal of Applied Chemistry, 10, 29-32.

[7] Ndiaye, B., Cissé, O.B.K., Ayessou, N., Baldé, S., Cissé, M., Diop, C.M., et al. (2018) Potentialités technologiques par l'évaluation biochimique de la farine des tu-bercules du souchet Cyperus esculentus L. Afrique Science, 14, 209-214.

[8] Imam, T., Aliyu, F. and Umar, H. (2013) Preliminary Phytochemical Screening, Elemental and Proximate Composition of Two Varieties of Cyperus esculentus (Tiger Nut). Nigerian Journal of Basic and Applied Sciences, 21, 247-251. https://doi.org/10.4314/njbas.v21i4.1

[9] Prakash, N. and Ragavan, B. (2009) Phytochemical Observation and Antibacterial Activity of Cyperus esculentus L. Ancient Science of Life, 28, 16-20.

[10] El-Naggar, E. (2017) Biological Effect of Tiger Nut (Cyperus esculentus L.) Oil on Healthy and Hypercholesterolemia Rats. Syrian Journal of Agricultural Research, 4, 133-147.

[11] Ebojele, F.O. and Ezenwanne, E.B. (2014) The Effect of Aqueous Extract of Cyperus esculentus on Some Liver Functional Indices in Rabbit. International Journal of Basic, Applied and Innovative Research IJBAIR, 3, 8-13.

[12] Allouh, M.Z., Daradka, H.M. and Ghaida, J.H.A. (2015) Influence of Cyperus esculentus Tubers (Tiger Nut) on Male Rat Copulatory Behavior. BMC Complementary and Alternative Medicine, 15, 1-7. https://doi.org/10.1186/s12906-015-0851-9

[13] Alhassan, A.W., John, M., Yusuf, A. and Yarube, I.U. (2016) The Pro-Tective Effect 
of Hydro-Methanolic Extract of Tiger Nut (Cyperus esculentus 1.) on PentyleneteTrazole Induced Seizures in Mice. Nature and Science, 14, 57-62.

[14] Ndiaye, B., Ayessou, N.C., Balde, S.R.W., Mady, C., Diop, C.M., et al. (2018) Propriétés galactogènes des tubercules de souchet Cyperus esculentus. International Journal of Innovation and Scientific Research, 39, 1-6.

[15] AFNOR French Association of Normalization (2011) Colorimetry Part 4: Chromatic Space $L^{\star} a^{\star} b$ CIE 1976. Paris, 8.

[16] Bernat, N., Cháfer, M., Chiralt, A. and González-Martínez, C. (2015) Development of a Non-Dairy Probiotic Fermented Product Based on Almond Milk and Inulin. Food Science and Technology International, 21, 440-453. https://doi.org/10.1177/1082013214543705

[17] AOAC (Prénom) (1990) Official Method of Analysis Association of Official Analytical Chemists. AOAC International Publisher, Gaithersburg.

[18] Kizzie-Hayford, N., Jaros, D., Zahn, S. and Rohm, H. (2016) Effects of Protein Enrichment on the Microbiological, Physicochemical and Sensory Properties of Fermented Tiger Nut Milk. LWT, 74, 319-324. https://doi.org/10.1016/j.lwt.2016.07.067

[19] Granito, M. and Alvarez, G. (2006) Lactic Acid Fermentation of Black Beans (Phaseolus vulgaris): Microbiological and Chemical Characterization. Journal of the Science of Food and Agriculture, 86, 1164-1171. https://doi.org/10.1002/jsfa.2490

[20] Schuck, P., Mahaut, M., Jeantet, R. and Brulé, G. (2000) Les produits industriels laitiers. Lavoisier TEC et DOC Editions.

[21] Imbachí-Narváez, P.C., Sepúlveda-Valencia, J.U. and Rodriguez-Sandoval, E. (2017) Effect of Modified Cassava Starch on the Rheological and Quality Properties of a Dairy Beverage Prepared with Sweet Whey. Food Science and Technology, 39, 134-142. https://doi.org/10.1590/1678-457x.28017

[22] Ogbonna, A.C., Abuajah, C.I. and Ukeme, E.A. (2013) Quality Comparison of Flavoured and Non-Flavoured Yoghurts from Animal and Vegetable Milk Sources. Food Biology, 2, 24-28.

[23] Ajibade, D., Olusegun, F. and James, O. (2015) An Evaluation of the Nutritional Qualities of Yoghurt Prepared from Different Plant Milk Sources. African Journal of Agriculture and Food Security, 3, 142-144.

[24] Ezeonu, C.S., Tatah, V.S., Nwokwu, C.D. and Jackson, S. (2016) Quantification of Physicochemical Components in Yoghurts from Coconut, Tiger Nut and Fresh Cow Milk. Advances in Biotechnology \& Microbiology, 1, Article ID: 555573. https://doi.org/10.19080/AIBM.2016.01.555573

[25] Abu-Jdayil, B. and Mohameed, H. (2002) Experimental and Modelling Studies of the Flow Properties of Concentrated Yogurt as Affected by the Storage Time. Journal of Food Engineering, 52, 359-365. https://doi.org/10.1016/S0260-8774(01)00127-3

[26] Kora, E.P. (2004) Interactions physico-chimiques et sensorielles dans le yaourt brassé aromatisé: Quels impacts respectifs sur la perception de la texture et de la flaveur? PhD Thesis, INAPG (AgroParisTech).

[27] Corredig, M. and Dalgleish, D.G. (1999) The Mechanisms of the Heat-Induced Interaction of Whey Proteins with Casein Micelles in Milk. International Dairy Journal, 9, 233-236. https://doi.org/10.1016/S0958-6946(99)00066-7

[28] Topdaş, E.F., Çakmakçı, S. and Çakıroğlu, K. (2017) The Antioxidant Activity, Vitamin C Contents, Physical, Chemical and Sensory Properties of Ice Cream Supplemented with Cornelian Cherry (Cornus mas L.) Paste. Kafkas Universitesi 
Veteriner Fakultesi Dergisi, 23, 691-697. https://doi.org/10.9775/kvfd.2016.17298

[29] González-Martınez, C., Becerra, M., Cháfer, M., Albors, A., Carot, J. and Chiralt, A. (2002) Influence of Substituting Milk Powder for Whey Powder on Yoghurt Quality. Trends in Food Science \& Technology, 13, 334-340. https://doi.org/10.1016/S0924-2244(02)00160-7

[30] Mor-Mur, M. and Yuste, J. (2003) High Pressure Processing Applied to Cooked Sausage Manufacture: Physical Properties and Sensory Analysis. Meat Science, 65, 1187-1191. https://doi.org/10.1016/S0309-1740(03)00013-5

[31] Sengupta, S. and Bhowal, J. (2017) Optimization of Ingredient and Processing Parameter for the Production of Spirulina Platensis Incorporated Soy Yogurt Using Response Surface Methodology. Journal of Microbiology, Biotechnology and Food Sciences, 6, 1081-1085. https://doi.org/10.15414/jmbfs.2017.6.4.1081-1085

[32] Samah, M.I., Azza, M.F. and Yaser, M.E. (2014) Functional and Nutritional Properties of Stirred Yoghurt Supplemented with Silymarin and Its Impact on Chronic Hepatic Damage. World Journal of Dairy \& Food Sciences, 9, 36-50. 